UDC 811.111:81'42

DOI https://doi.org/10.32838/2710-4656/2021.4-2/10

Semenist I. $V$.

orcid.org/0000-0002-0847-8856

Borys Grinchenko Kyiv University

Makhachashvili R. K.

orcid.org/0000-0002-4806-6434

Borys Grinchenko Kyiv University

\title{
VERBAL MODELLING OF INNOVATIVE EDUCATIONAL COMMUNICATION IN THE DIGITAL DISCOURSE
}

The paper main focus is the inquiry into the verbal premises and patterns of comprehensive structuring of the innovative educational communication in the digital discourse (innovative educational communication in the digital ambient as construed by the transformative neological strata of modern European and Oriental languages of international communication - English, Spanish, French, Chinese, Japanese, accordingly). The problem of theoretical and methodological substantiation of cross-cutting principles, directions, mechanisms, and results of qualitative dynamics of linguistic macro- and microstructures of thesaurus in the realm of digital educational communication, as a consolidated linguistic object, is investigated in depth. Mosaic, simulation, and multidimensional approaches to understanding complex dynamic linguistic phenomena and entities, prioritized by this methodological context, allowed us to identify the ontological nature of lexical innovations of the globalized languages in the sphere of innovative educational communication. The ICT, e-learning, hybrid learning, digital competences thesaurus, that facilitates innovative educational communication, is structured to define and categorize the key components of innovative cyber terminology, instrumental to e-learning environment construction and functioning. Suggested is the ICT Thesaurus macro-, micro- and mega-structures modelling based on three groundwork principles: 1) Intranet educational anthroposphere (the anthropic environment within World Wide Web); 2) Outernet educational anthroposphere (e-reality components, functions outside the realm of World Wide Web); 3) Technogenic educational anthroposphere (transoriented anthropic environment components with an anthropic-for-congenous substituted onthological parameter). All units, listed and clusterised in the Thesaurus are supplied with a dominant or recessive conceptual marker or a combination of markers, indicative ofthe unit allegiance to the corresponding ontological categories of cyber-anthropospheric e-learning environment.

The dynamic interaction of the structural tiers of the ICTs content plane within the strata of innovative educational communication is characterized by the anthropogenic parameters of the content plane, mediated by the subjective and collective cognitive experience of digital education stakeholders, mediated by the use of globalized languages.

Key words: innovative educational communication, ICT, e-learning, hybrid learning, digital competences thesaurus, logosphere, thesaurus modelling, phenomenological marker.

Introduction and state-of-the-art overview. At the turn of the XX - XXI centuries, science acquires the status of extremely effective and dynamic tools of human activity, which determines the interest of scientists in pragmatic aspects and problems of cognitive theory to increase the effectiveness of scientific work by traditional classical means and innovative systems of artificial intelligence $[2 ; 3 ; 4 ; 30]$.

The network of research space of modern linguistic explorations provides an opportunity to determine the problems of language coding, transcription and mapping of different spheres of actual and conditional reality in linguocognitive $[50 ; 52 ; 51 ; 12 ; 14]$, linguistic and cultural $[7 ; 23$; $26 ; 40 ; 46]$, discursive-communicative $[37 ; 40 ; 48]$, synergetic [33], activity [7; 8; 44] planes.

As an integral product of civilization, modern computer reality has become an independent being. Within it, electronic media act not only as a means of transmitting information or interaction, but also reveal their own world-creating, meaningmaking, and, as a consequence, language-forming potential $[29 ; 3 ; 6]$. Computer being (CB - a term after V. Kutyriev [38; 39]) is defined as a complex, 
multidimensional sphere of synthesis of reality, human experience, and activity, mediated by the latest digital and information technologies; it is the object of study of a wide range of humanities.

In philosophy, computer being is interpreted as a special type of substance - material and ideal reality in the aggregate of all forms of its development [4; 18; 29]; in anthropology - as an environment for the implementation of "post-humanistic" tendencies of anthropogenesis $[7 ; 5 ; 8 ; 45]$; in psychology as a psychosomatic and emotional plane [20; 25]; in culturology - as a sphere of spiritual experience $[17 ; 11 ; 9 ; 24]$, in sociology - as a system of multilevel, multidirectional social relations $[1 ; 10 ; 32]$.

The linguistic aspect of the study of computer being at the turn of the century is determined by objective historical and geopolitical preconditions: cyberization, globalization, informatization of world society, Americanization of world culture, due to which modern English, mostly its American variety, is a priority linguistic and communicative environment of the primary language coding of elements of computer being and its mapping [15; 16], exported to globalized languages across the world.

The problem of theoretical and methodological substantiation of cross-cutting principles, directions, mechanisms and results of qualitative dynamics of linguistic macro- and microstructures of vocabulary in the realm of computer being, as a consolidated linguistic object, is still waiting to be studied. Consideration of this issue requires the involvement of the phenomenological perspective of the study of complex linguistic objects, given the definition of the main task of phenomenological epistemology knowledge of the full system of facts of consciousness [43], constituting the objective world [30;31;21].

Objective. The paper overall objective is the inquiry into the verbal premises and patterns of comprehensive structuring of the innovative educational communication in the digital discourse (generally understood as educational commuication in the digital ambient as construed by the transformative innivative (neological) strata of modern European and Oriental languages of international communication - English, Spanish, French, Chinese, Japanese, accordingly, and facilitated by innovative digital media and communicative formats).

Main findings. The main hypothesis of the study is that the typological characteristics of innovative ICT, e-learning, HYBRID LEARNING, digital competences thesaurus as a macro-object of a phenomenological investigation determine the specificity of static configuration and dynamic interaction of formal and substantive constituents of its microstructure. 3157 of speech and linguistic units - innovations that relate to multi-substrat areas, objects and phenomena of computer being - in usage serve as research empirical database, selected by canvas sampling out of conventional lexicographic sources, specificized registers of lexicographic innovations of electronic format and English periodicals of the timespan from 2019 to 2021. Within the outlined methodological dimension, the "phenomenological" language unit is defined as its codifying ability to record the results of cognitive experience and manifestation (the term after V. Babushkin, [24]) in it the substantive characteristics of cognizable objects and phenomena. .

The linguistic adaptation of the phenomenological approach to the theoretical and methodological understanding of the dynamics of the vocabulary of modern European and Oriental languages in computer life is based on the concept of the logosphere, synthetically understood as: 1) elements of different spheres of life [41]; 2) the zone of integration of thought-speech continuums (linguo) of cultures $[27 ; 28]$.

The turn of the XX-XXI centuries is determined by a significant acceleration of the enrichment of the vocabulary of modern natural languages [15; $55 ; 33 ; 48 ; 52]$, which determines the need for holistic linguistic research of innovative industries.

Such a study of the vocabulary replenishment of modern European and Oriental languages corresponds to a new integrative direction phenomenological neolinguistics. The global innovative logosphere of computer being, a component of the international language logosphere, is considered as a plurality of verbal innovations, which are phenomenological correlates of the elements of computer being. Phenomenological neolinguistics provides the researcher with the innovative logosphere of computer existence with the functional integrative methodology and analysis procedures, the application of which allows comprehensive coverage of the relationship between the principles of ultra-dense verbalization of this dimension of reality and mechanisms of neologization, nomination, language reference.

The proposed linguophenomenological approach to the study of the object of study helps to solve the scientific problem of holistic modeling of processes and results of replenishment of the vocabulary of the highly dynamic system of modern languages in general and its individual areas at the turn of XX-XXI centuries. 
The object sphere of phenomenological neolinguistics consists of elements of the logosphere (in particular, the linguistic innovative logosphere of computer existence) in the priority determinative dialectical interaction with the constructs of existence - space, time, substance, phenomenon, essence-corresponding to the object field "ontological neolinguistics"; constructs of knowledge/cognition episteme, concept,concept-corresponding totheobject field "epistemological neolinguistics", and constructs of human consciousness/self-consciousness identification, identity, individuality - corresponding to the object field "anthropological neolinguistics".

This inquiry is based on the initial position on the phenomenological nature of computer lexical innovations of modern European and Oriental languages (namely, the ability to identify, embody and structure elements of the corresponding sphere of being), which enables and provides complex determinative interaction of different substratum and abstract ) parameters of the global language innovation logosphere of computer existence. In the process of research, the algorithm of ontospheric and anthropospheric paradigmatic systematization of general language innovative computer terms is introduced.

Within the phenomenological approach (E. Husserl, R. Ingarden, M. Mamardashvili, G. Shpet) $[21 ; 31 ; 34 ; 42 ; 42 ; 56]$ global semiotic integration of macro- and microstructures of the language innovative logosphere of computer existence identified as provided and realized due to the deterministic interaction of multisubstrate (linguistic, spatio-spatial, essential, anthropological and social) parameters of this logosphere, given the significant synchronous density of rates and results of parallel development of verbal, ontological and anthropological planes of computer being. Logocentric perspective on computer verbal innovations of modern globalized languages determines their phenomenological nature through the identification of symbolic (structuralsemantic) substrate of these linguistic innovations as an empirical source and result of manifestation of substantive characteristics of reality.

For deductive and inductive determination of types, volume, qualitative characteristics, and direction of dynamics of the content of units of the microstructure of Global innovative logosphere of computer being the elements of a method of conceptual analysis (R. Langacker) $[13 ; 14]$ in combination with elements of a method of phenomenological reduction (E. Husserl, V. Babushkin, M. Heidegger) [24; 31; 54] are applied by the end-to-end epistemic deconstruction of the object of analysis (linguistic innovation unit) from the empirical sign substrate, which corresponds to the dialectical concept of "phenomenon", through tiers of the intensional and the extensional of the content plane to the substantive characteristics of the referent, corresponding to the dialectical concept of "essence".

Identified and parameterized in the course of our study is a significant density and, to some extent, redundancy of innovative verbalization of the conceptual and semantic segment of language in the field of innovative educational communication in the digital discourse is, in our opinion, a specific (by extensional characteristics of newly formed language units) (term according to V. Karasyk $[36$, p. 279]) and communicative relevance (in terms of the concept of Z. Popova and I. Sternin [49, p. 275]) of this conceptual and semantic segment for the global language community. In this way, the significance of understanding the elements of computer reality for a specific language community can be inductively verified.

In turn, empirically clear and observable situational parallelism of the processes of emergence and development of a wide range of different substrate innovative elements of computer being:

- essential elements (space, time, substance),

- gnoseological elements (information, episteme, etc.), anthropological elements (existential state, type of identity, etc.),

- lingual correlates (language sign, language form, language meaning, language content)

determines the theoretical and methodological relevance of defining the problem of positioning this segment of linguistic reality - the general verbal innovations of the English language to denote elements, objects and phenomena of computer life, as special, specific features, consolidated, consistent and systemic type linguistic embodiment (modeling, pictureing) of reality.

Parameterization principles of a concept of "logos" in the paradigm of the humanities in general, linguophilosophy, and linguistics - in particular, allow to identify the features of innovative educational communication in the digital discourse as a complex object system pertaining the following parameters: Ubiquity (inclusiveness); Onthotcentrizm; Integrativity; Automorphism; Normativity; Lingual substantiality; Phenomenology of thesaurus units; Information-capacity; Referential and semiotic isomorphism of the referent and meaning.

Note that through the fragmented set of qualitative features, logosphere is tangent to the concepts 
of complex system simulators linguistic-mental outlook, such as:

- Model of the world / world view (inclusive, integrative, self-identity);

- Language picture of the world (phenomenology of linguistic constituents - the ability to summarize and signify objects of reality);

- Noosphere (onthotsentrism, info-capacity);

- Communication/discourse.

For the listed set of features the integral notion of IECDD (innovative educational communication in the digital discourse) stands as a semantic synthesis of these concepts (see Figure 1):

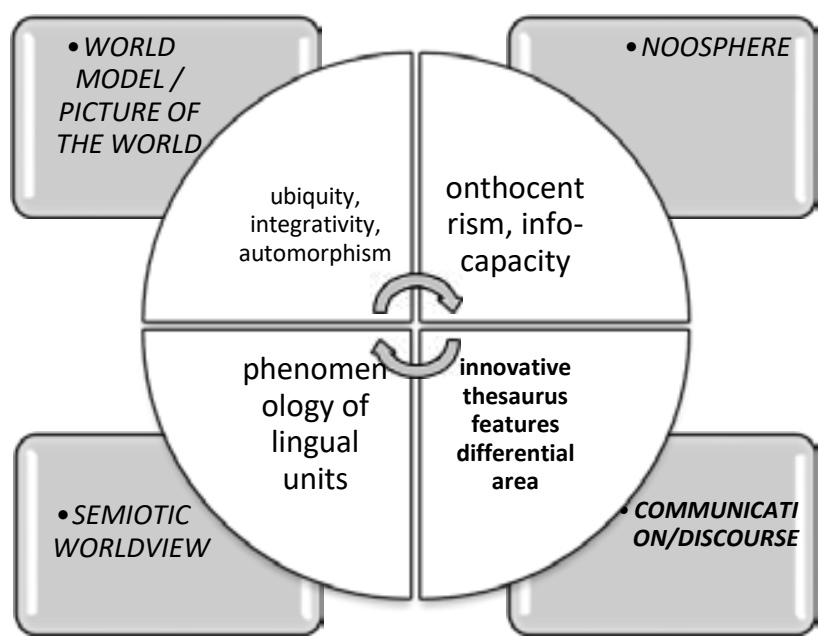

Fig. 1. Innovative educational communication in digital discourse model

The specific differential features of logosphere as alinguistic-onthological,linguistic-phenomenological object are:

- Normativity - arising from the parametric features of the concept of "logos" - (while maintaining the characteristics of dynamic variation and logosphere);

- Lingual substantivity - phenomenological ("actualization") status of meta-language signs membranes in reality;

- The principle of isomorphism of the signified and meaning.

The outer conthour of a separate national (in this case - English) logosphere in synchrony within this study is positioned as an innovative English logosphere. Innovative English logosphere itself (multidimensional, of complex, dynamic system) is a kind of "test-ground" for linguistic actualization of life. That is, linguistic (lexical-semantic) representation of new modes of reality exists within reach of the human mind, and therefore is subject to immediate perception and comprehension.
Itisconsideredappropriate toseparateconfiguration and parameterization of a specified macrophenomenon of linguistic research - English innovative computer being logosphere. Thus, the network innovation and relevant subsystems in modern English, the English innovative ICT, e-learning, hybrid learning, intercultural competences logosphere (multidimensional, complex, dynamic system) is the most comprehensive quantitative and qualitative terms of language representation of the universe "test site" linguistic actualization of being, determined by a number of qualifying conditions of its emergence, existence and development, including:

1) exhaustive synchronization process of the object, phenomenological and anthropological field of computer being and development processes of the ICT, e-learning, hybrid learning, intercultural competences meta-language;

2) exhaustive output of parameterization isomorphism of onthological (substance phenomenological) and anthropic, respectively and computer structures of reality;

3) flexibility, adaptability and dynamic potential of the vocabulary of the English language in correlation with the ICT, e-learning, hybrid learning, intercultural competences sphere (that is fulfilled, in particular through info-capacity, sign hybridization, the evolution of the basic onthological and functional features of neologisms in relevant areas).

In view of the foregoing, the innovative ICT, e-learning, hybrid learning and digital competences logosphere (ICL) as a verbal premise of innovative educational communication in the digital discourse is defined as:

a) a syncretic, consolidated within its semantic scope, plurality of English verbal units that are the asymptotically (i.e. in unlimited approximation) exhaustive embodiments of substantive and factual elements of modern computer being.

b) as a vertically integrated at the macro and micro levels plurality of ICT, e-learning, hybrid learning, intercultural competences thesaurus, its typological specificity are relatively exhaustive phenomenological correlates multi-substrat elements of computer being.

Given signs of the logosphere as a specific onthological and linguistic-semiotic object, it is possible to distinguish the following substantial characteristics of innovative computer logosphere:

- Theability to synthesize substances of attributes, parameters and properties of onthological objects and phenomena and innovative meta-verbal units, respectively; 
- Ability to asymptotic (very close to exhaustive) implementing of the substantive and factual elements of modern ICT, e-learning, hybrid learning, intercultural competences being at their own substance as a whole and at the level of substantial characteristics of discrete meta-verbal units (terms) that constitute the relevant innovation thesaurus logosphere.

- Exhaustive semantic, formal and constructive density of implementation (reveal) of substantive and factual elements of modern computer being in the onthological, epistemological and anthropological plane.

The meaningfuly discrete unit of ontological denotatum for innovative computer terminos is perceived as a substanteme - the in-depth and essential element of the content substance of a computer verbal innovation that is identified both deductively and inductively. Deductive identification is by layering phenomenological diagnosis $[21 ; 35 ; 47]$ of the content elements of the GICL microstructure parallel phenomenological reduction and content of computer elements to the definition of being "phenomenological points of intersection" - isomorphic or correlative content substant components. Inductively substanteme is identified through procedural component analysis and correlation of multi-level conceptual structures of the ICTs content.

Substanteme is a power indicator of the distribution of elements of the content plan function of a language innovative computer terminology, which attracts actual/implicit/potential services to the ICTs meaning pattern. "Substant genome" is a phenomenologically identified essential "module" of ICTs meaning - the area of absolute convergence of qualitative characteristics of the element of the ICTs content plane and the corresponding qualitative possibilities of their actualization.

According to the nature of the dialectical consistent correlation of the tiers of the structure of the ICTs content plan within the opposition "essence/phenomenon", where tier (1) "ontological denotatum" corresponds to the dialectical concept of "essence", tier (3) "lingual denotatum" the dialectical concept of "phenomenon", the discrete elements of tier (3) of the ICTs content plane (seme) and the discrete elements of tier (1) of the ICTs content plane (substantemae) are isomorphic.

Inventory of representative components configuration onthological referents ICTs inhomogeneous system is the hierarchicy of substantemes involving hierarchical qualifiers (substant taxa of the content of ICL) and their corresponding discrete elements subordinated hypohiperonimichnym principle (Table 1).

Table 1

Substant elements of ICT, e-learning, hybrid learning, intercultural competences ICTs meaning chirerarchy

\begin{tabular}{|c|c|c|}
\hline \multirow{2}{*}{$\begin{array}{l}\text { Sabstant } \\
\text { taxon }\end{array}$} & \multicolumn{2}{|c|}{ Substant unit } \\
\hline & Substant hyperunit & Sbstant hypounit \\
\hline $\begin{array}{l}\text { |substance } \\
\text { type|: }\end{array}$ & $\begin{array}{ll}\text { - } & \mid \text { computer being } \mid \\
\text { - } & \mid \text { substance quality } \mid \\
\text { - } & \mid \text { virtuality } \mid \\
- & \mid \text { network } \mid\end{array}$ & $\begin{array}{ll}- & \mid \text { Technogenesis } \mid \\
- & \mid \text { cybermorphism } \mid\end{array}$ \\
\hline $\begin{array}{l}\text { |substance } \\
\text { affiliation|: }\end{array}$ & $\begin{array}{ll}- & \mid \text { cb object } \mid \\
- & \mid \text { cb subject } \mid \\
- & \mid \text { cb simulacrum } \mid\end{array}$ & - $\mid$ digital skill $\mid$ \\
\hline $\begin{array}{l}\text { |substance } \\
\text { duration|: }\end{array}$ & $\begin{array}{ll}- & \text { |space|: } \\
- & \text { |time|: } \\
\end{array}$ & - $\mid$ singularity $\mid$ \\
\hline $\begin{array}{l}\text { |substance } \\
\text { fracture|: }\end{array}$ & $\begin{array}{ll}\text { - } & \text { |space| } \\
\text { - } & \text { |time|: }\end{array}$ & - |COMMUNICATION $\mid$ \\
\hline
\end{tabular}

The highest indicator of representativeness at all levels of the microstructure of the content plane (from deep to surface) within the total sample of ICTs in innovative digital educational communication across European and Oriental languages reveal the following discrete substant elements:

- | TYPE OF SUBSTANCE: COMPUTER BEING |;

- | SUBSTANT QUALITY: TECHNOGENESIS |;

- | SUBSTANT DURATION: SPACE |;

- I SUBSTANT AFFILIATION: SUBJECT OF COMPUTER BEING |.

Dynamicinteraction of structurallevelofthe content within innovative ICT, e-learning, hybrid learning, digital competences being thesaurus is characterized by the gradual expansion of the onthological referents (Table 2).

Table 2

Sample representative combinations of the eicts substant elements pertaning to the merger zone of innovative ICT, e-learning, hybrid learning, digital competences thesaurus

|SUBSTANT TYPE: COMPUTER BEING |

|SUBSTANT AFFILIATION: | |SUBSTANT QUALITY: DIGITAL SKILL| TECHNOGENESIS|

|CB OBJECT

|CB SUBJECT

'[COMMUNICATION]

Conclusions. Mosaic, simulation, and multidimensional approaches to understanding complex 
dynamic linguistic phenomena and entities, prioritized by this methodological context, allowed us to identify the ontological nature of innovative ICT, e-learning, hybrid learning, digital competences thesaurus in innovative educational communication (namely, the ability to embody and structure elements of the relevant realm of life independently from the filter of human experience), which enables and provides a complex determinative interaction of multisubstrate (linguistic, existential and anthropological) parameters of the innovative logosphere of computer being.
The dynamic interaction of the structural stages of the innovative ICT, e-learning, hybrid learning, digital competences thesaurus content plane within the linguistic premises of innovative educational communication is characterized by the expansion of the ontological denotatum, resulting in isolation/absorption/replacement, or partial isolation/absorption/replacement of anthropogenic parameters of the content plane, mediated by the subjective and collective cognitive experience of digital education stakeholders, who are speakers of globalized languages.

\section{References:}

1. Bell D. Social Framework of the Information Society. Oxford : Oxford U. Press, 1987. 315 p.

2. Davis E. Techgnosis: Myth, Magic and Mysticism in the Age of Information. N.Y. : New York Publishers, Inc., 2001. $377 \mathrm{p}$.

3. Gelernter D. Virtual Realism. Oxford : Oxford University Press, 1998. 138 p.

4. Gunts E. Icon in stone and steel. The Baltimore Sun. 2000. Sept. 24. P. 21-22.

5. Hamilton G. Virtual reality. Business Week.1993, Issue 3. P. 12-22.

6. Hausser R. Foundations of Computational Linguistics. Springer : Verlag Berlin Heidelberg, 1999. 534 p.

7. Heeter C. Implications of new interactive technologies for conceptualizing communication. Media use in the information age. Hillsdale, NJ: Erlbaum, 1989. P. 85-108.

8. Heim M. Virtual Reality: Practice and Promice. LA : Wesport Publishers, 1994. 233 p.

9. Jacob W. What Dreams May Come. Time. 1998, Issue 18. P. 29-32.

10. Johnson F. Shall I Compare Thee to a Swarm of Insects? Searching for the Essence of the World Wide Web. The New York Times. 2003. P. 10-12.

11. Knight S. Making authentic cultural and linguistic connections. Hispania. 1994. Vol. 77. P. 289-294.

12. Lakoff G. Women, fire and dangerous things. Chicago : CUP, 1987. 614 p.

13. Langacker R. W. Cognitive Grammar. The Oxford Handbook of Cognitive Linguistics. Oxford : Oxford Univ. Press, 2007. P. 421-462.

14. Langacker R. W. Concept, Image, and Symbol: The Cognitive Basis of Grammar. Berlin \& New York : Mouton de Gruyter, 1991. 395 p.

15. Makhachashvili R., Models and Digital Diagnostics Tools for the Innovative Polylingual Logosphere of Computer Being Dynamics. Italian-Ukrainian Contrastive Studies: Linguistics, Literature, Translation. Monograph. Peter Lang GmbH Internationaler Verlag der Wissenschaften, Berlin, 2020. P. 99-124.

16. Makhachashvili R., Semenist I. ICT Thesaurus Modelling Recommendations (based on innovations of European and Oriental languages). Studia Filologiczne, 7, 2020. P. 117-128.

17. Monnin A. Humanity and Digital Characters in Virtual Worlds: Crossing the Fictional Boundaries. Posthumanity : Merger and Embodiment. Oxford, UK : Inter-Disciplinary Press, 2010. P. 126-131.

18. Nyce J. M. From Memex to Hypertext. NY: Kahn Publications, 1994. 472 p.

19. Searle J. Minds, Brains, and Science. Oxford: Oxford U. Press, 1984. 142 p.

20. Suler J. Human Becomes Electric. From Books To Cyberspace Identities. NC : NCU Press, 2009. P. 21-25.

21. Zahavi D. Husserl's Phenomenology. Palo Alto : Stanford University Press, 2003. 312 p.

22. Андреева И. В. Ценностная картина мира как лингвистическая и философская категорія. Аналитика культурологии. 2006. № 3. С. 14-21.

23. Андрейчук Н. I. Семіотика лінгвокультурного простору Англії кінця XV - початку XVII століття. Львів: Видавництво Львівської політехніки, 2011. 277 с.

24. Бабушкин В. У. Феноменологическая философия науки - критический анализ. М. : Наука, 1985. $246 \mathrm{c}$

25. Баксанский О. Е., Кучер Е. Н. Когнитивное репрезентирование как механизм виртуализации реальности. Вируалистика: экзистенциальные и эпистемологические аспекты. М. : Прогресс-Традиция, 2004. C. $262-285$.

26. Бардина Н. В. Античная матрица нашей души. Одесса : Астропринт, 2009. 288 с.

27. Барт Р. Избранные работы: Семиотика: Поэтика. М. : Прогресс, 1989. 616 с.

28. Бахтин М. М. Эстетика словесного творчества. М. : Искусство, 1979. 424 с.

29. Борчиков С. А. Метафизика виртуальности. Труды лаборатории виртуалистики. 2000. Вып. 8. С. 29-33. 
30. Будко В. В. Адекватность научного познания. Харьков : Логос, 1990. 154 с.

31. Гуссерль Э. Картезианские размышления. СПб. : Наука, 2001. 516 с.

32. Девтерев И. В. Философский анализ феномена интерактивной научной деятельности в INTERNET (феноменологический, эвристический и прагматический аспекты). Киев : 2000.188 с.

33. Єнікєєва С. М. Система словотвору сучасної англійської мови: синергетичний аспект (на матеріалі новоутворень кінця XX - початку XXI століть). Київ : 2011. 438 с.

34. Ингарден Р. Введение в феноменологию Эдмунда Гуссерля. Москва : Дом интеллектуальной книги, 1999. $267 \mathrm{c}$.

35. Камша В. П., Камша Л. С., Камша Ю. В. Про кібернетику другого етапу НТР. Складні системи і проиеси. 2010. № 1 (17). С. 25-41.

36. Карасик В. И. Языковой круг: личность, концепты, дискурс. Волгоград: Перемена, 2002. 477 с.

37. Колегаева И. М. Текст как единица научной и художественной коммуникации. Одесса : Изд-во ОГУ, 1991. $121 \mathrm{c}$.

38. Кутырев В. А. Культура и технология: борьба миров. Москва: Прогресс-Традиция, 2001. 336 с.

39. Кутырев В. А. Пост-пред-гипер-контр-модернизм: концы и начала. Bопросы философии. 1998. № 5. С. 35-41.

40. Кухаренко В. А. Интепретация текста. Одесса: Латстар, 2002. 288 с.

41. Лосев А. Ф. Вещь и имя. Бытие. Имя. Космос. Москва : Мысль, 1993. С. 805-872.

42. Мамардашвили М. К., Пятигорский А. М. Символ и сознание. Метафизические рассуждения о сознании, символике и языке. Москва : Школа, 1997. 216 с.

43. Мамардашвили М. К. Как я понимаю философию. Избр. ст., докл., выступ., інтервью. Москва : Прогресс, 1999. 415 с.

44. Мартинюк А. П. Конструювання гендеру в англомовному дискурсі. Харків: Константа, 2004. 292 с.

45. Мартинюк С. С. Метафізичні виміри людського буття. Запоріжжя : Запорізький державний університет, 2001. $198 \mathrm{c}$.

46. Маслова В. А. Введение в когнитивную лингвистику. Москва : Флинта, 2007. 296 с.

47. Мерло-Понти М. Феноменологія сприйняття. Київ: Український Центр духовної культури, 2001. $552 \mathrm{c}$.

48. Морозова А. К. Проблема значения в свете современных семантических теорий. Вісник ХНУ. 2004. № 635. С. 114-117.

49. Попова 3. Д., Стернин И. А. Когнитивная лигвистика. Москва : АСТ, Восток-Запад, 2007. 315 с.

50. Потапенко С. І. Орієнтаційна семантика: дискурсивне втілення. Вісник Львівського університету. Вип. 52. 2011. С. 253-261.

51. Селиванова Е. А. Когнитивная ономасиология. Монография. Київ : Фитосоциоцентр, 2000. 248 с.

52. Селиванова Е. А. Процессы неологизации в ракурсе динамики этносознания. Лексико-грамматические инновации в современных восточнославянских языках. Днепропетровск: Пороги, 2007. С. 57-60.

53. Степанов Ю. С. В трёхмерном пространстве языка: Семиотические проблемы лингвистики, философии, искусства. Москва : Наука, 1986. 336 с.

54. Хайдеггер М. Язык. Москва : Фолио, 2003. 374 с.

55. Шепель Ю. А. Міжгалузева термінологічна омонімія у сучасній англійській мові. Дніпродзержинськ : ДДТУ, 2010. 335 с.

56. Шпет Г. Явление и смысл (Феноменология как основная наука и ее проблемы). Москва : Наука, $2001.219 \mathrm{c}$

\section{Семеніст І. В., Махачашвілі Р. К. ВЕРБАЛЬНЕ МОДЕЛЮВАННЯ ІННОВАЦЙНОЇ ОСВІТНЬОЇ КОМУНІКАЦІЇ У ЦИФРОВОМУ ДИСКУРСІ}

Основну увагу в роботі зосереджено на дослідженні вербальних передумов та закономірностей комплексної структуризаиії інновачійної освітньої комунікації у ицфровому дискурсі (інноваційна освітня комунікація в циирровому середовищі визначається трансформачійними неологічними шарами сучасних європейських та східних мов міжнародного спілкування: англійської, іспанської, франиузької, китайської, японської відповідно). Досліджено більш поглиблено проблему теоретичного та методологічного обтрунтування наскрізних принщипів, напрямів, механізмів та результатів якісної динаміки лінгвістичних макро- та мікроструктур тезаурусу у сфері иифрової освітньої комунікації як консолідованого мовного об'єкта. Мозайчний, стимулячійний $і$ багатовимірний підходи до розуміння складних динамічних мовних явищ та сутностей, які визначено пріоритетом у иьому методологічному контексті, дозволили виявити онтологічну природу лексичних інновачій глобалізованих мов у сфері інноваційної освітньої комунікаиії. Тезаурус IKT, електронного навчання, гібридного навчання, 
цифрових компетентностей, що визначає інноваційне освітнє спілкування, побудований таким чином, щоб визначити та класифікувати ключові компоненти інновачійної кібертермінології, які сприятимуть побудові та функціонуванню середовища електронного навчання. Запропоновано моделювання макро-, мікро- та мегаструктур IКТ-тезаурусу, щьо базується на трьох основних приниипах: 1) Інтранет-освітня антропосфера (антропне середовище в Інтернеті); 2) зовнішня антропосфера освіти (компоненти електронної реальності, що функиіонують поза сферою Всесвітньої павутини); 3) техногенна освітня антропосфера (переорієнтовані компоненти антропогенного середовища із заміщеним онтологічним параметром, антропним для вродженого). Всі перелічені та згруповані в Тезаурусі підрозділи мають домінуючий або рецесивний конщептуальний маркер чи комбіначію маркерів, щзо свідчить про прихильність одиниці відповідним онтологічним категоріям кібер-антропосферного середовища електронного навчання.

Динамічна взаємодія структурних рівнів площуини змісту IКТ у шарах інноваційної освітньої комунікацї характеризується антропогенними параметрами площини змісту, опосередкованою суб 'єктивним та колективним когнітивним досвідом стейкголдерів иифрової освіти та використанням глобалізованих мов.

Ключові слова: інновачійна освітня комунікачія, IКТ, електронне навчання, гібридне навчання, иифровий тезаурус компетентностей, логосфера, моделювання структур тезауруса, феноменологічний маркер. 